\title{
Local anesthetic systemic toxicity: Continuing Professional Development
}

\author{
Kariem El-Boghdadly, MBBS · Ki Jinn Chin, MBBS
}

Received: 1 June 2015/Revised: 17 September 2015/Accepted: 7 December 2015/Published online: 29 January 2016

(C) Canadian Anesthesiologists' Society 2016

\begin{abstract}
Purpose Regional anesthesia is enjoying a renaissance due in part to the advent of ultrasound guidance and the development of new techniques such as tissue plane blocks and local infiltration analgesia. The purpose of this Continuing Professional Development module is to provide practitioners with an understanding of the current state of knowledge surrounding local anesthetic systemic toxicity (LAST) in order to help them prevent and manage this complication more effectively.

Principal findings The causes of LAST are multifactorial, but recognized risks include patient factors, drug doses, pharmacokinetics, and choice of regional anesthetic technique. Local anesthetic systemic toxicity produces a biphasic course of clinical events that generally begin with central nervous system excitation followed by inhibition. At the same time, it causes cardiovascular compromise due to dysrhythmias, myocardial depression, and reduced systemic vascular resistance. Clinical presentation can be highly variable, however, and atypical presentations are not uncommon. Local anesthetic systemic toxicity is prevented by careful choice and dosing of drugs, aspiration before injection, dose fractionation, use of intravascular markers and ultrasound guidance. The management of LAST includes adequate oxygenation and ventilation, seizure termination, maintenance of circulation, and intravenous lipid emulsion therapy.
\end{abstract}

K. El-Boghdadly, MBBS · K. J. Chin, MBBS ( $\varangle)$

Department of Anesthesia, Toronto Western Hospital, 399

Bathurst Street, McL 2-405, Toronto, ON M5T 2S8, Canada

e-mail: gasgenie@gmail.com
Conclusions Local anesthetic systemic toxicity is a potentially lethal condition with protean manifestations, and anesthesiologists must understand its risks, prevention, and safe management.

\section{Objectives of this Continuing Professional Development} (CPD) module:

After reading this module, the reader should be able to:

1. List the risk factors for local anesthetic systemic toxicity (LAST);

2. Formulate a plan to prevent or minimize the risk of LAST in the setting of regional anesthesia;

3. Recognize both the typical and the atypical clinical features of LAST;

4. Describe the appropriate management of the minor and major presentations of LAST.

Local anesthetic systemic toxicity (LAST) is a lifethreatening complication that must be considered whenever local anesthetic (LA) is administered. Contemporary studies indicate that LAST is relatively rare $(0.7-1.8$ per 10,000 epidurals $^{1,2}$ and 2.0-2.8 per 10,000 peripheral nerve blocks $^{1,3}$ thanks to the emphasis placed on preventative measures and technological advances such as ultrasound guidance. ${ }^{3}$ Nevertheless, given the resurgence of interest in the perioperative use of local anesthetics (LAs), particularly with newer techniques that utilize relatively high volumes, such as the transversus abdominis plane (TAP) block and local infiltration analgesia (LIA), practitioners must remain familiar with the condition. Guidelines for the management of LAST have been published by the American Society of Regional Anesthesia and the Association of Anaesthetists of Great 
Britain and Ireland in 2010.,5 The purpose of this Continuing Professional Development module is to summarize the most recent literature regarding LAST and to integrate the resulting material with existing management guidelines. This will help practitioners understand the current state of knowledge surrounding LAST and encourage them to take steps to prevent and manage this complication more effectively.

\section{Mechanisms and clinical presentation of LAST}

Distribution, metabolism, and clearance of LA

Factors governing the rate of systemic absorption of LA, and thus its peak plasma concentration and the time to reach that peak, include the mass of drug injected and tissue perfusion at the site. ${ }^{6}$ There is rapid distribution to well-perfused tissues, including the brain, heart, liver, and lungs, which explains the clinical manifestations of LAST. The aminoamide LAs are highly protein bound, particularly to $\alpha_{1}$-acid glycoprotein, and only the free fraction is available for metabolism or to act at target sites. The pathway for subsequent clearance depends on the specific agent used. Aminoamide LAs (e.g., lidocaine, bupivacaine, ropivacaine) undergo enzymatic degradation in the liver, whereas aminoester LAs (e.g., procaine, chloroprocaine, tetracaine) undergo hydrolysis by plasma pseudocholinesterase. ${ }^{7}$ Renal excretion of unchanged LA is minimal.

\section{Central nervous system (CNS) toxicity}

Local anesthetics block intracellular voltage-gated fast sodium channels in neuronal tissue, inhibiting depolarization and preventing neuronal transmission. The effects of rising LA plasma concentrations become apparent in the CNS beginning with blockade of cerebral cortical inhibitory pathways. ${ }^{8}$ This produces symptoms and signs of CNS excitation, including sensory and visual disturbances, muscle twitching, and eventually convulsions. At higher plasma concentrations, excitatory neurons become blocked, and a second phase of CNS depression occurs, leading to unconsciousness, coma, and respiratory arrest.

\section{Central nervous system clinical features}

In a review of 93 reported cases of LAST in the literature, the most common signs of the complication were seizures $(68 \%)$, followed by agitation (11\%) or loss of consciousness $(7 \%) .{ }^{9}$ Early manifestations are protean in nature and severity, and include perioral paresthesia, dizziness, dysarthria, confusion, mental obtundation, and visual or auditory disturbances. While these early signs are described in only a small number of case reports, ${ }^{9}$ minor cases of LAST are likely underreported. Local anesthetic systemic toxicity should therefore be strongly considered in the presence of any acute onset of neurological symptom or change in mental state, be it agitation or obtundation.

\section{Cardiovascular toxicity}

At the myocardial cellular level, LAs block potassium and calcium channels, leading to three predominant pathophysiologic effects on the cardiovascular system (CVS): dysrhythmias, myocardial depression, and changes in systemic vascular resistance.

Local anesthetics block sodium channels in conducting cells, particularly the bundle of His, and render the resting membrane potential more negative. This reduces the rate of depolarization and propagation of action potentials, which ultimately prolongs the PR, QRS and ST intervals, and increases the risk of both bradyarrhythmias and re-entrant tachyarrhythmias. ${ }^{6}$ Additional potassium channel inhibition enhances sodium channel blockade, increases re-entrant dysrhythmias, reduces myocyte repolarization, and prolongs the QT interval. ${ }^{8}$

The mechanism of LA-induced myocardial depression is multifactorial and complex. Intracellular calcium release is reduced by calcium channel blockade and inhibition of the myocardial sodium-calcium channel pump. This impairs excitation-contraction coupling, thereby reducing contractility. Local anesthetics also impair mitochondrial energy metabolism by interfering with oxidative phosphorylation and recruitment of free fatty acids, which depletes stores of intracellular adenosine triphosphate. Finally, LAs also interfere directly with the production of cyclic adenosine monophosphate.

Systemic effects contributing to cardiovascular collapse include suppression of the baroreceptor reflex as well as a direct reduction in vascular tone. ${ }^{10}$

\section{Cardiovascular system clinical features}

Although the most feared consequences of LAST are malignant ventricular arrhythmias and cardiac arrest, there is a wide spectrum of CVS features that may be more commonly seen. These signs range from excitatory phenomena, such as hypertension and tachycardia (caused by sympathetic activation during the CNS excitatory phase of LAST), to signs of CVS depression (from direct myocardial toxicity), including hypotension, bradycardia and asystole. Dysrhythmias were the most common feature amongst reported cases and encompassed bradyarrhythmias, narrow- and 
wide-complex tachyarrhythmias, ventricular ectopy, and ST segment changes. ${ }^{9}$ It is worth pointing out that $12 \%$ of reported cases presented with asystole.

\section{Cardiovascular collapse/CNS ratio}

The cardiovascular collapse/CNS $(\mathrm{CC} / \mathrm{CNS})$ ratio is the ratio of drug dose required to cause catastrophic CVS collapse to the drug dose required to produce seizures. Among the commonly used LAs, racemic bupivacaine has the lowest CC/CNS ratio, followed by levobupivacaine, ropivacaine, and lidocaine. ${ }^{11}$ This is consistent with the fact that bupivacaine has a greater affinity for myocardial sodium, potassium and calcium channels compared with lidocaine, levobupivacaine, and ropivacaine. ${ }^{8}$ A low $\mathrm{CC} /$ CNS ratio is associated with more cardiotoxic agents. Conversely, LAs with higher CC/CNS ratios have a theoretically greater margin of safety, as the earlier occurrence of convulsions facilitates recognition of LAST and early intervention to prevent progression along the spectrum of CVS toxicity to circulatory collapse. Nevertheless, it is important to remember that CVS toxicity can occur without preceding clinical features of CNS toxicity, regardless of the agent used. ${ }^{9}$

\section{Clinical presentation and timing}

The majority of LAST events occur within several minutes of LA injection and present with CNS signs, which may or may not be accompanied by CVS changes. ${ }^{9,12}$ It is important to point out that the presentation is often atypical in terms of both timing and clinical manifestations. Onset of symptoms can be delayed up to 60 min following a bolus injection, and CVS signs of toxicity can occur in the absence of any CNS features. ${ }^{9}$ This latter scenario may be more common in patients who are heavily sedated or under general anesthesia.

The sine qua non of LAST is an elevated LA plasma concentration, and this can occur in one of three ways: inadvertent intraarterial injection, intravenous injection, or systemic absorption, each of which has a characteristic temporal course.

Local anesthetic systemic toxicity associated with intraarterial injection classically occurs during performance of nerve blocks in the head and neck, (e.g., stellate ganglion, interscalene, or deep cervical plexus blocks) in which there is inadvertent injection of LA into an artery supplying the brain. Central nervous system symptoms, usually seizures, occur very rapidly. ${ }^{12}$ However, this rapidity also means that delivered doses tend to be small and thus progression to CVS collapse is uncommon. Recovery is equally swift as LA is quickly redistributed from the cerebral circulation.
Inadvertent intravenous injection of LA can occur during the performance of any regional anesthetic technique but tends to result in LAST only if larger volumes $(>5-10 \mathrm{~mL})$ are injected. Symptoms usually occur within five minutes ${ }^{9}$ and can rapidly progress in severity if appropriate measures are not taken.

Local anesthetic systemic toxicity resulting from systemic absorption of LA is characterized by a delayed presentation (20-30 min or longer following a bolus injection) $)^{12-14}$ and usually occurs when a relatively high dose of LA has been administered in the presence of other risk factors. Local anesthetic systemic toxicity may also occur in the setting of continuous infusion of LA, in which case, the onset may be hours to days after commencing the infusion. ${ }^{9}$ Symptoms can be expected to last until drug metabolism reduces plasma concentrations to below the toxic threshold, and prolonged monitoring and supportive therapy may be required.

\section{Risk factors for LAST}

Risk factors for LAST can be divided broadly into those that increase the plasma concentration for a given dose of LA or those that increase the susceptibility of an individual patient to the pathophysiologic effects of LAs. These risk factors include drug physicochemical properties, administration dynamics, and patient factors. Dose reduction should be considered when any of these risk factors are present.

\section{Age considerations}

The plasma concentration of the binding protein $\alpha_{1}$-acid glycoprotein is significantly reduced at birth, which increases the plasma free fraction of LA. Hepatic enzyme systems are also immature, and LA doses should therefore be reduced by $15 \%$ in babies less than four months old. ${ }^{15}$

Although peak plasma concentrations and protein binding remain largely unchanged in elderly patients, clearance of LAs is reduced ${ }^{16}$ due in part to reduced organ perfusion and metabolic function. Degenerative diseases and other comorbidities are more prevalent in the elderly, and this can increase their susceptibility to the systemic effects of LA. In addition, age-related changes in electrophysiology render their peripheral nervous system more sensitive to the effects of LA, ${ }^{17}$ and thus, a $10-20 \%$ dose reduction should be considered.

\section{Renal dysfunction}

The pharmacokinetics of amide LAs, such as bupivacaine and ropivacaine, are not significantly affected by changes 
in renal function. ${ }^{18,19}$ Although higher total plasma LA concentrations have been reported in patients with end-stage renal failure (attributed to a hyperdynamic circulation and increased extraction of LA from the injection site), this is offset by a rise in $\alpha_{1}$-acid glycoprotein, and thus, free plasma concentrations are largely unchanged. ${ }^{20}$ Routine dose reduction is therefore usually unnecessary, except in uremic patients with metabolic acidosis who may be more susceptible to LAST as a result.

\section{Cardiac disease}

Several factors contribute to an increased risk of LAST in patients with severe cardiac dysfunction, including reduced hepatic perfusion and drug clearance, and elevated LA tissue concentrations due to prolonged circulation time. Dose adjustment is unnecessary in cases of mildto-moderate heart failure where tissue perfusion is preserved, but it is encouraged in advanced heart failure. ${ }^{16}$ Conduction disorders may predispose to CVS toxicity; therefore, the use of less-cardiotoxic LAs, such as ropivacaine or levobupivacaine, is recommended in conjunction with judicious drug dosing.

\section{Hepatic dysfunction}

The reduced clearance of LAs in subjects with hepatic dysfunction is offset by an increased volume of distribution, and their plasma concentrations are similar to those in healthy subjects. ${ }^{16}$ Synthesis of $\alpha_{1}$-acid glycoprotein is maintained even in end-stage liver disease, which provides an additional buffer of safety. Consequently, patients with isolated hepatic insufficiency do not require dose adjustment for single-shot blocks. However, reduced clearance becomes a consideration in patients with advanced hepatic dysfunction - complicated by other organ failure - who receive continuous LA infusion or repeated bolus injections, and therefore, doses should be limited accordingly.

\section{Pregnancy}

Regional anesthesia is preferred over general anesthesia in pregnant patients due to potential risks of difficult intubation, gastric aspiration, aorto-caval compression, and theoretical first trimester fetal developmental defects ${ }^{21}$ however, progressive physiological changes place them at a higher risk of LAST. Increased cardiac output from the second trimester onwards may increase absorption of LA and thus plasma concentration. ${ }^{22}$ Epidural venous engorgement may increase epidural LA absorption and the risk of intravenous catheter migration. Protein binding progressively decreases throughout pregnancy, with its nadir at term, thus increasing the free plasma LA concentration. ${ }^{23}$ Biochemical and hormonal changes in pregnancy increase neuronal sensitivity to LA and may also reduce the threshold for seizures in LAST. ${ }^{24}$ It is therefore prudent to limit LA dosing for peripheral and central neuraxial blockade in parturients, particularly at later stages of pregnancy. ${ }^{16}$

Block site and technique

In highly vascular sites of injection, there is an increased risk of both inadvertent direct intravascular injection of local anesthetic and enhanced systemic absorption. These include the intercostal space, the psoas compartment (lumbar plexus), and the gluteal area (proximal sciatic nerve). Blocks in these areas have been associated with LAST despite adherence to maximum recommended doses.

In recent years, blocks involving the deposition of large doses of LA in intermuscular tissue planes (e.g. TAP block) as well as at the site of surgical incision (e.g. LIA) have become increasingly popular. Local anesthetic systemic toxicity has been reported following TAP blocks, ${ }^{13,25}$ and it appears that doses used in clinical practice produce peak plasma concentrations that often exceed threshold levels associated with toxicity. ${ }^{26,27}$ The risk of LAST with TAP blocks is significant for several reasons: large injection volumes $(\geq 20 \mathrm{~mL}$ per side in adults) are used to ensure adequate spread, bilateral blocks are often performed to cover midline incisions, and the TAP contains a rich network of vessels. In addition, these blocks are commonly performed for post-Cesarean delivery analgesia, and as discussed, these patients may be more susceptible to LAST.

Although pharmacokinetic studies of LIA in total knee $^{28,29}$ and hip replacement surgery ${ }^{30,31}$ suggest that free plasma ropivacaine concentrations are below the mean threshold levels for toxicity established in volunteers, a significant number of study patients still experienced minor symptoms of LAST. A recent case report of significant and prolonged LAST following LIA highlights the risk to these patients who are often older with multiple comorbidities. ${ }^{14}$

\section{Prevention of LAST}

Appropriate local anesthetic dosing

From a safety perspective, the appropriate dose (mass) of LA is the lowest that will achieve the desired extent and duration of anesthesia or analgesia. ${ }^{4}$ However, the maximum dose permissible in any given patient is a more difficult question to answer. For a given dose, plasma and effect-site concentrations will vary depending on site 
of administration as well as on individual pharmacokinetic differences. Although specific plasma concentration levels are often quoted as thresholds for LAST, ${ }^{32}$ these represent the mean of a normal distribution in healthy volunteers and do not account for interindividual variability in the susceptibility to LAST.

These observations have called into question the relevance of maximum recommended doses ${ }^{16}$ and per kilogram dosing in adults. ${ }^{33}$ Nevertheless, they remain useful guidelines and should not be exceeded without careful consideration of the risk-benefit ratio, particularly in underweight patients (Table 1). More importantly, it must be recognized that LAST may occur despite adherence to these limits. In overweight patients, dosing should be based on lean rather than absolute body weight and adjusted downwards where possible for higher-risk block techniques and patients. If LA combinations are used, the risk for LAST should be assumed to be additive and the dose of each agent reduced accordingly.

\section{Use of safer LAs}

Both ropivacaine and levobupivacaine have higher $\mathrm{CC}$ :CNS ratios than racemic bupivacaine, and it is therefore logical to prefer their use where long-acting LAs are desired. However, this does not negate the need for additional precautions as both agents can still cause significant LAST. ${ }^{9,13,26,34}$

Early detection of vascular puncture and intravascular injection

\section{Aspiration Before Injection}

Gentle aspiration, a simple step to detect inadvertent vascular puncture, should always be performed before LA injection. There is, however, a significant false-negative rate with both epidural catheters ${ }^{35}$ and peripheral nerve blocks. $^{36}$

\section{Fractionated dosing with markers of intravascular injection}

Local anesthetics should be injected in increments of 3-5 $\mathrm{mL}$, and injections should be separated by at least one circulation time (30-45 sec). This theoretically allows detection of intravascular injection before an excessive dose has been administered. The most commonly used marker is epinephrine. An intravascular dose of epinephrine $15 \mu \mathrm{g}$ ( $3 \mathrm{~mL}$ of a 1:200 000 solution) will generally produce $\mathrm{a} \geq 10$ beats $\cdot \mathrm{min}^{-1}$ increase in heart rate or $\geq 15 \mathrm{mmHg}$ rise in systolic blood pressure. The hemodynamic response is attenuated, however, in patients on beta-blockers, ${ }^{37}$ the elderly, and patients who are sedated or under general anesthesia. ${ }^{38}$ Its use in labour epidural analgesia is also controversial due to the possibility of false-positive results from simultaneous uterine contractions and a lower threshold for increases in heart rate, as well as concerns of exacerbating hypertension in preeclampsia. ${ }^{38}$ While there has been a recent trend to avoid epinephrine in peripheral nerve blockade because of concerns that local vasoconstriction may exacerbate neurotoxicity, this has yet to be clinically proven. Finally, epinephrine has the additional advantage of reducing peak LA plasma concentration, ${ }^{39}$ and thus, on balance, the advantages of epinephrine far outweigh its limitations and potential risks.

Ultrasound-guided peripheral nerve blockade

Recent evidence indicates that the incidence of LAST is lower following ultrasound-guided peripheral nerve blockade compared with non-ultrasound-guided techniques. ${ }^{3}$ This may be explained by (1) the reduction in required LA doses, (2) the ability to visualize vessels at risk of puncture, (3) the inherent fractionation and pauses that accompany the recommended approach of visually assessing spread of small boluses of LA (hydrolocation), and (4) detection of possible intravascular injection by the absence of visible spread.

\section{Management of LAST}

Preparation and vigilance

Intravenous access, oxygen and standard monitoring (pulse oximetry, blood pressure, echocardiogram $)^{40}$ should be routine in all patients receiving significant doses of LA. Resuscitation equipment and medications must be available together with a printed checklist of management steps. ${ }^{41}$ Assembly of a "LAST kit" is encouraged in centres where large doses of LA are routinely administered (Table 2). ${ }^{41}$

Maintain airway, oxygenation, and ventilation

Avoiding hypoxemia and acidosis (metabolic or respiratory) is critical in managing LAST. Both factors have been shown to exacerbate LAST in laboratory studies and, if allowed to persist, may promote progression to cardiac arrest and hinder return of spontaneous circulation. It should be pointed out, however, that hyperventilation and consequent respiratory alkalosis may also be detrimental and should be avoided. ${ }^{42}$ 
Table 1 Suggested dosing recommendations for commonly used local anesthetics

\begin{tabular}{llllll}
\hline Agent & Plain solution & & \multicolumn{2}{l}{ With Epinephrine } \\
\cline { 2 - 3 } \cline { 5 - 6 } & Maximum Dose $\left(\mathrm{mg} \cdot \mathrm{kg}^{-1}\right)$ & Maximum Dose $(\mathrm{mg})$ & & Maximum Dose $\left(\mathrm{mg} \cdot \mathrm{kg}^{-1}\right)$ & Maximum Dose $(\mathrm{mg})$ \\
\hline Lidocaine & $5 \mathrm{mg} \cdot \mathrm{kg}^{-1}$ & $350 \mathrm{mg}$ & $7 \mathrm{mg} \cdot \mathrm{kg}^{-1}$ & $500 \mathrm{mg}$ \\
Mepivacaine & $5 \mathrm{mg} \cdot \mathrm{kg}^{-1}$ & $350 \mathrm{mg}$ & $7 \mathrm{mg} \cdot \mathrm{kg}^{-1}$ & $500 \mathrm{mg}$ \\
Bupivacaine & $2 \mathrm{mg} \cdot \mathrm{kg}^{-1}$ & $175 \mathrm{mg}$ & $3 \mathrm{mg} \cdot \mathrm{kg}^{-1}$ & $225 \mathrm{mg}$ \\
Levobupivacaine & $2 \mathrm{mg} \cdot \mathrm{kg}^{-1}$ & $200 \mathrm{mg}$ & $3 \mathrm{mg} \cdot \mathrm{kg}^{-1}$ & $225 \mathrm{mg}$ \\
Ropivacaine & $3 \mathrm{mg} \cdot \mathrm{kg}^{-1}$ & $200 \mathrm{mg}$ & $3 \mathrm{mg} \cdot \mathrm{kg}^{-1}$ & $250 \mathrm{mg}$ \\
\hline
\end{tabular}

Adapted from:

1. Berde CB, Strichartz, GR. Local anesthetics. In: Miller RD (Ed.). Miller's Anesthesia, 8th ed. Philadelphia: Elsevier; $2015: 1043$

2. Dadure C, Sola C, Dalens B, Capdevila X. Regional anesthesia in children. In: Miller RD (Ed.). Miller's Anesthesia, 8th ed. Philadelphia: Elsevier; 2015: 2718

3. American Academy of Pediatrics; American Academy of Pediatric Dentistry, Cote CJ, Wilson S; Work Group on Sedation. Guidelines for monitoring and management of pediatric patients during and after sedation for diagnostic and therapeutic procedures: an update. Pediatrics 2006; 118: $2587-602$

\section{Terminate and suppress seizures}

Prolonged seizure activity exacerbates metabolic acidosis and must be treated promptly. Benzodiazepines are recommended as first-line therapy, as they do not generally provoke excessive cardiovascular instability. ${ }^{43}$ Propofol, on the other hand, should be used only if benzodiazepines are unavailable or if seizures are refractory to treatment, because it may exacerbate subclinical cardiotoxicity and promote progression to circulatory collapse, especially if large doses are administered. $^{43}$ Low-dose succinylcholine has been suggested in refractory seizures to reduce metabolic acidosis from muscle contractions, ${ }^{4}$ with the caveat that it will only mask but not terminate seizure activity.

\section{Maintain tissue perfusion}

In the event of cardiac arrest, standard Advanced Cardiac Life Support (ACLS) algorithms for cardiopulmonary resuscitation should be followed, including indications for cardioversion and uterine displacement in pregnant patients. Chest compressions should be initiated immediately and maintained until return of spontaneous circulation. Local anesthetic does not directly damage cardiac myocytes, and as long as tissue hypoxia is avoided, full recovery is possible even after prolonged cardiopulmonary resuscitation. Maintaining adequate circulation also accelerates the recovery process by facilitating removal of LA from cardiac tissue. In the absence of rapid recovery following advanced life support measures and intravenous lipid emulsion (ILE) therapy, early consideration should be given to cardiopulmonary bypass as a means of circulatory support, ${ }^{4}$ as significant time may be required to initiate the procedure even in a tertiary centre. ${ }^{44}$
Use vasopressor and antiarrhythmic drugs judiciously

As highlighted above, the emphasis in cardiac arrest is on maintaining circulation with chest compressions or cardiopulmonary bypass, while awaiting elimination of LA or reversal of its effects with ILE. Epinephrine may be used to improve systemic vascular resistance and myocardial contractility but should be administered in small doses of $<1 \mu \mathrm{g} \cdot \mathrm{kg}^{-1} \cdot{ }^{4}$ Larger doses have been shown to promote tachyarrhythmias in animal studies and were associated with a poorer outcome compared with ILE therapy. ${ }^{43}$ Vasopressin has also been linked with adverse pulmonary and metabolic outcomes in animal models of LAST and should be avoided if possible. ${ }^{4}$

Of the various antiarrhythmic drugs mentioned in ACLS algorithms, only amiodarone is recommended in LAST. Lidocaine and other sodium channel blockers (e.g., procainamide) should be avoided, while beta-blockers and calcium channel blockers should not be administered due to their cardiodepressant and vasodilatory effects.

Intravenous lipid emulsion therapy

This is arguably the most important advance in LAST management and indeed in the management of an increasing range of toxicological syndromes. ${ }^{45}$ The mechanisms by which ILE is thought to work include (1) its effect as an intravascular lipid "sink" that binds and inactivates a significant amount of the lipophilic local anesthetic molecules, (2) promotion of mitochondrial fatty acid metabolism and ATP synthesis in myocardial cells, and (3) a direct inotropic effect due to increased intracellular myocardial calcium content. Thus far, the above mechanisms are incompletely understood. 
Table 2 Management of local anesthetic systemic toxicity (LAST)

\section{PREPARATION}

- Ready access to a Local Anesthetic Systemic Toxicity Kit; suggested contents include a printed checklist for managing LAST, ${ }^{5,41}$ a bag of $20 \%$ lipid emulsion, intravenous tubing, syringes, and needles

\section{PREVENTION}

- Appropriate LA dosing

- Use of less cardiotoxic LAs

- Aspiration before injection

- Fractionated dosing

- Use of markers of intravascular injection

- Ultrasound-guidance for local anesthetic injection

DETECTION

CNS Signs (may be subtle or absent)

- Excitatory-agitation, confusion, seizures

- Depressive-Mental slowing, reduced level of consciousness, coma, apnea

- Non-specific-perioral paresthesia, tinnitus, diplopia, metallic taste
CVS Signs (may present in isolation)

- Hyperdynamic - hypertension, tachydysrhythmias

- Hypotension

- Bradycardia

- Conduction block

- Asystole

- Ventricular arrhythmia

\section{INITIAL MANAGEMENT}

- Stop injecting LA

- Call for help and the Local Anesthetic Systemic Toxicity Kit

- Maintain the airway and secure if necessary; ventilate with $100 \%$ oxygen

- Confirm or establish intravenous access

- Terminate and suppress seizures with benzodiazepines, propofol (if no cardiovascular instability), or thiopental

- Consider intravenous lipid emulsion if CNS symptoms persist or recur

- Consider drawing blood to measure LA plasma concentration if there is no delay to definitive treatment 
Table 2 continued

\begin{tabular}{|c|}
\hline TREATMENT \\
\hline $\begin{array}{l}\text { Cardiac Arrhythmias } \\
\text { - In circulatory arrest, follow Advanced Cardiac Life Support algorithms with } \\
\text { the modifications listed below } \\
\text { - Oxygenation, ventilation, and cardiac compressions are paramount } \\
\text { - Administer intravenous lipid emulsion as soon as possible } \\
\text { - Alert nearest cardiopulmonary bypass facility } \\
\text { - } \quad \begin{array}{l}\text { Reduce epinephrine dose to }<1 \mu \mathrm{g} \cdot \mathrm{kg}^{-1} \text {, and where possible, administration } \\
\text { - }\end{array} \text { - Amould be preceded by initiation of intravenous lipid emulsion therapy } \\
\text { - } \text { sodium channel blockers, or vasopressin } \\
\text { especially where long-acting LAs were administered }\end{array}$ \\
\hline $\begin{array}{l}\text { 20\% Intravenous lipid emulsion therapy } \\
\text { [Values in brackets are for a } 70-\mathrm{kg} \text { adult] } \\
\text { - Bolus } 1.5 \mathrm{~mL} \cdot \mathrm{kg}^{-1} \text { over } 1 \mathrm{~min}[100 \mathrm{~mL}] \\
\text { - Continuous infusion } 15 \mathrm{~mL} \cdot \mathrm{kg}^{-1} \cdot \mathrm{hr}^{-1}\left[1,000 \mathrm{~mL} \cdot \mathrm{hr}^{-1}\right] \\
\text { If persistent cardiovascular instability or deterioration after } 5 \text { minutes: } \\
\text { - Repeat the same bolus up to two further times } \\
\text { - Double the infusion rate to } 30 \mathrm{~mL} \cdot \mathrm{kg}^{-1} \cdot \mathrm{hr}^{-1}\left[2,000 \mathrm{~mL} \cdot \mathrm{hr}^{-1}\right] \\
\text { - Continue infusion for } 10 \mathrm{~min} \text { after return of cardiovascular stability } \\
\text { - Maximum 30-min cumulative dose of } 10 \mathrm{~mL} \cdot \mathrm{kg}^{-1}[700 \mathrm{~mL}]\end{array}$ \\
\hline FOLLOW-UP \\
\hline $\begin{array}{l}\text { - Transfer to a clinical area with appropriate monitoring, equipment, and staff } \\
\text { for }>12 \mathrm{hr} \text { monitoring } \\
\text { - Regular clinical review to exclude pancreatits, including serial amylase or } \\
\text { lipase for } 2 \text { days } \\
\text { - Report cases and use of ILE to www.lipidrescue.org }\end{array}$ \\
\hline
\end{tabular}

\begin{abstract}
Adapted from:
1.American Society of Regional Anesthesia and Pain Medicine checklist for treatment of local anesthetic systemic toxicity. ${ }^{41}$

2.Association of Anaesthetists of Great Britain and Ireland safety guideline: Management of severe local anaesthetic toxicity. ${ }^{5}$

CNS = central nervous system; CVS = cardiovascular system; LA = local anesthetic
\end{abstract}

There is presently insufficient evidence to conclude that one ILE preparation is superior to others, but most reported clinical experience has been with Intralipid® ${ }^{\circledR} 20 \%$ (Fresenius Kabi, AG, Bad Homburg, Germany), which is a soy-based ILE of long-chain triglycerides. Propofol is not an appropriate alternative for ILE therapy.
Intravenous lipid emulsion has a high therapeutic index, ${ }^{46}$ and early administration should be considered in suspected LAST, ${ }^{4}$ both to help reverse CNS symptoms as well as to interrupt the progression towards CVS collapse. Nevertheless, ILE is not a substitute for effective cardiopulmonary resuscitation, which is 
essential for an optimal outcome in LAST-associated cardiac arrest.

Current dosing recommendations are based on lean body mass and are summarized in Table 2. For an average $70-\mathrm{kg}$ adult, the initial dose may be conveniently remembered as a 100 $\mathrm{mL}$ bolus of $20 \%$ ILE followed by a $1,000 \mathrm{~mL} \cdot \mathrm{hr}^{-1}$ infusion. If hemodynamic instability continues, two further boluses may be given and the infusion rate doubled, with a maximum recommended dose of $10 \mathrm{~mL} \cdot \mathrm{kg}^{-1}$ in the first $30 \mathrm{~min}$.

Most of the concerns regarding adverse effects of ILE are associated with prolonged administration, ${ }^{46}$ although peripheral thrombophlebitis and hypersensitivity reactions are possible with acute administration. Clinical reports to date indicate that ILE therapy in LAST is very safe, but serial measurements of amylase or lipase for up to $48 \mathrm{hr}$ are recommended to exclude pancreatitis. ${ }^{5}$ In patients with egg or soy allergy, the potential benefit of ILE in reversing CVS collapse probably outweighs the theoretical risk of an allergic reaction. It should also be emphasized that the ensuing lipemia can interfere with laboratory measurements of electrolytes or hemoglobin.

Post-event management

The decision whether to proceed or continue with surgery following recovery from a LAST event should be made on a case-by-case basis with input from all stakeholders. Regardless, patients should be monitored for recurrence of symptoms, ideally for more than $12 \mathrm{hr}^{4,9,14}$ If ILE was administered, cases should be reported to the registry at www.lipidrescue.org.

\section{Clinical case}

A 40-kg 88-yr-old female presents with an intertrochanteric femoral neck fracture and is scheduled for a dynamic hip screw. She has a background of hypertension, mild heart failure, and hypercholesterolemia. She takes bisoprolol 5 $\mathrm{mg}$, atorvastatin $20 \mathrm{mg}$, and acetylsalicylic acid $81 \mathrm{mg}$ daily. In the operating room, she is alert and oriented. Standard monitoring is instituted with saturations of $98 \%$ on oxygen 6 $\mathrm{L} \cdot \mathrm{min}^{-1}$ via face mask, a blood pressure of $152 / 89 \mathrm{mmHg}$, and a heart rate of 66 beats. $\mathrm{min}^{-1}$.

You perform a landmark-guided fascia iliaca block with $0.5 \%$ bupivacaine $30 \mathrm{~mL}$ with epinephrine $2.5 \mu \mathrm{g} \cdot \mathrm{mL}^{-1}$, followed by a spinal anesthetic with hyperbaric bupivacaine $10 \mathrm{mg}$ and fentanyl $15 \mu \mathrm{g}$.

After performing the blocks, the patient's saturations are $98 \%$ on oxygen; her blood pressure is $136 / 82 \mathrm{mmHg}$, and her heart rate is 65 beats $\cdot \mathrm{min}^{-1}$.
Instructions for completing the continuing professional development (CPD) module:

1. Read the current article and the references indicated in bold.

2. Go to: http://www.cas.ca/Members/CPD-Online and select the current module: Local anesthetic systemic toxicity.

3. Answer the multiple-choice questions regarding the case scenario.

4. Once you have entered all of your answers, you will have access to experts' explanations for all the possible choices.

5. Participants may claim up to four hours of CPD for a total of 12 credits under Section 3 of the CPD program of the Royal College of Physicians and Surgeons of Canada.

\section{La toxicité systémique des anesthésiques locaux}

\section{Résumé}

Objectif L'anesthésie régionale jouit d'un regain d'intérêt, grâce en partie à l'avènement de l'échoguidage et à la mise au point de nouvelles techniques, telles que les blocs de la paroi abdominale et l'analgésie par infiltration locale. L'objectif de ce module de développement professionnel continu est d'offrir aux praticiens des informations qui leur permettront d'être plus au fait de l'état actuel de nos connaissances concernant la toxicité systémique des anesthésiques locaux (TSAL), ce qui les aidera à éviter et à prendre en charge cette complication de façon plus efficace.

Constatations principales Les causes de TSAL sont plurifactorielles; toutefois, parmi les risques reconnus, il faut citer les facteurs liés au patient, les dosages médicamenteux, la pharmacocinétique et le choix de la technique d'anesthésie régionale. La toxicité systémique des anesthésiques locaux produit une série biphasée d'événements cliniques qui débutent en général par une excitation du système nerveux central, suivie par une inhibition. En même temps, la TSAL affecte le système cardiovasculaire en provoquant des dysrythmies et une dépression myocardique, et en réduisant la résistance vasculaire systémique. La présentation clinique de cette complication peut être très diverse toutefois, et les présentations atypiques ne sont pas rares. On peut prévenir la toxicité systémique des anesthésiques locaux 
en choisissant et en dosant les médicaments avec soin, en procédant systématiquement à une aspiration avant l'injection, en fractionnant les doses, ainsi qu'en utilisant des marqueurs intravasculaires et l'échoguidage. La prise en charge de la TSAL comprend une oxygénation et une ventilation adaptées, l'interruption des convulsions, le maintien de la circulation et le traitement par émulsion lipidique par voie intraveineuse.

Conclusion La toxicité systémique des anesthésiques locaux est une condition potentiellement fatale qui se manifeste de façon protéiforme, et les anesthésiologistes doivent comprendre ses risques, sa prévention et sa prise en charge sécuritaire.

\section{Objectifs de ce module de développement professionnel continu (DPC):}

Après avoir lu ce module, le lecteur devrait être en mesure de:

1. Énumérer les facteurs de risque de toxicité systémique des anesthésiques locaux (TSAL);

2. Formuler un plan qui permette de prévenir ou de minimiser le risque de TSAL dans le contexte d'une anesthésie régionale;

3. Reconnaître aussi bien les caractéristiques cliniques typiques qu'atypiques de TSAL;

4. Décrire la prise en charge adaptée des différentes présentations, mineures ou majeures, de TSAL.

La toxicité systémique des anesthésiques locaux (TSAL) est une complication potentiellement fatale qu'il faut avoir à l'esprit chaque fois que l'on administre un agent anesthésique local (AL). Les études contemporaines indiquent que la TSAL est relativement rare $(0,7-1,8$ par 10000 péridurales $^{1,2}$ et $2,0-2,8$ par 10000 blocs nerveux périphériques) $)^{1,3}$ grâce à l'emphase mise sur les mesures préventives et aux progrès technologiques tels que l'échoguidage. ${ }^{3}$ Ceci étant, en raison du regain d'intérêt pour l'utilisation périopératoire des anesthésiques locaux (AL), particulièrement dans le cas de techniques plus récentes qui utilisent des volumes relativement élevés, comme par exemple les blocs du muscle transverse de l'abdomen (TAP) et l'analgésie par infiltration locale, les praticiens ont le devoir de bien connaître cette condition. Des directives de prise en charge de la TSAL ont été publiées par l'American Society of Regional Anesthesia et par l'Association of Anaesthetists of Great Britain and Ireland en 2010., ${ }^{4,5}$ L'objectif de ce Module de développement professionnel continu est de résumer la littérature la plus récente concernant la TSAL et d'incorporer les informations qui en découlent dans les directives de prise en charge existantes. Ainsi, nous aiderons les praticiens à mieux saisir l'état actuel des connaissances concernant la TSAL et les encouragerons à prendre des mesures pour prévenir et prendre en charge cette complication de façon plus efficace.

\section{Mécanismes et présentation clinique de la TSAL}

Distribution, métabolisme et élimination (clairance) des AL

Parmi les facteurs régissant le taux d'absorption systémique des AL, et par conséquent leur concentration plasmatique maximale et le temps pour atteindre ce pic, citons la masse totale de médicament injecté et la perfusion tissulaire au site. ${ }^{6}$ La distribution d'AL est rapide vers les tissus bien perfusés, y compris le cerveau, le cœur, le foie et les poumons, ce qui explique les manifestations cliniques de TSAL. Les AL amino-amides sont fortement liés aux protéines, particulièrement à la glycoprotéine $\alpha_{1}$-acide, et seule la fraction libre est disponible pour le métabolisme ou pour agir au site cible. La voie de clairance subséquente dépend de l'agent utilisé. Les AL amino-amides (lidocaïne, bupivacaïne ou ropivacaïne par ex.) subissent une dégradation enzymatique dans le foie, alors que les $\mathrm{AL}$ amino-esters (par ex., procaïne, chloroprocaïne ou tétracaïne) sont hydrolysés par la pseudocholinestérase plasmatique. ${ }^{7}$ L'excrétion rénale d'AL inchangé est minime.

Toxicité au niveau du système nerveux central (SNC)

Les anesthésiques locaux bloquent les canaux sodiques voltage-dépendants dans le tissu neuronal, inhibant ainsi la dépolarisation et empêchant la transmission neuronale. Les effets d'une augmentation des concentrations plasmatiques d'AL deviennent alors apparents dans le SNC, tout d'abord par un blocage des voies inhibitrices corticales cérébrales. ${ }^{8}$ Ceci produit des symptômes et signes d'excitation au niveau du SNC, notamment des troubles sensoriels et visuels, des spasmes musculaires, puis finalement des convulsions. À des concentrations plasmatiques plus élevées, les neurones excitateurs deviennent bloqués, et une deuxième phase de défaillance du SNC survient, entraînant l'inconscience, le coma et l'arrêt respiratoire.

\section{Particularités cliniques du système nerveux central}

Dans un compte rendu portant sur 93 cas rapportés de TSAL dans la littérature, les signes les plus répandus de la complication étaient les convulsions (68\%), suivis par l'agitation $(11 \%)$ et la perte de conscience $(7 \%))^{9}$ Les 
premières manifestations sont de nature et de gravité protéiformes et comprennent la paresthésie périorale, les étourdissements, la dysarthrie, la confusion, l'obnubilation mentale et les troubles de la vision ou de l'audition. Bien que ces signes précoces ne soient décrits que dans un petit nombre de cas, ${ }^{9}$ il est probable que les cas mineurs de TSAL soient sous-rapportés. Par conséquent, il est impératif d'envisager une TSAL en présence de toute apparition soudaine de symptômes neurologiques ou de tout changement de l'état mental, qu'il s'agisse d'agitation ou d'obnubilation.

\section{Toxicité au niveau cardiovasculaire}

Au niveau de la cellule myocardique, les AL bloquent les canaux potassiques et calciques, ce qui provoque trois effets physiopathologiques prédominants au niveau du système cardiovasculaire (SCV): les dysrythmies, la dépression myocardique et des changements au niveau de la résistance vasculaire systémique.

Les anesthésiques locaux bloquent les canaux sodiques des cellules conductrices, particulièrement le faisceau de His, et rendent le potentiel de la membrane au repos plus négatif. Cela réduit le taux de dépolarisation et la propagation des potentiels d'action, ce qui, ultimement, prolonge les intervalles PR, QRS et ST, tout en augmentant à la fois le risque de bradyarythmies et de tachyarythmies par réentrée. ${ }^{6}$ Une inhibition supplémentaire du canal potassique favorise le blocage du canal sodique, ce qui augmente aussi les dysrythmies par réentrée, réduit la repolarisation du myocyte et prolonge l'intervalle QT. ${ }^{8}$

Le mécanisme sous-jacent à la dépression myocardique induite par les AL est plurifactoriel et complexe. La libération calcique intracellulaire est réduite par le blocage du canal calcique et l'inhibition de la pompe du canal sodique-calcique myocardique. Cela entrave le couplage excitation-contraction, réduisant ainsi la contractilité. Les anesthésiques locaux empêchent également le métabolisme de l'énergie mitochondriale en interférant avec la phosphorylation oxydative et le recrutement d'acides gras libres, ce qui vide les réserves intracellulaires d'adénosine triphosphate. Enfin, les AL interfèrent également de façon directe avec la production d'AMP cyclique.

Les effets systémiques contribuant à la défaillance cardiovasculaire comprennent la suppression du réflexe barorécepteur ainsi que la réduction directe du tonus vasculaire. $^{10}$

Particularités cliniques du système cardiovasculaire

Bien que les conséquences les plus redoutées d'une TSAL soient les arythmies ventriculaires malignes et l'arrêt cardiaque, il existe une vaste gamme de caractéristiques du SCV plus répandues. Ces signes vont de phénomènes excitateurs, comme l'hypertension et la tachycardie (provoquées par l'activation sympathique pendant la phase excitatrice sur le SNC de la TSAL), à des signes de dépression du SCV (causée par une toxicité myocardique directe), y compris l'hypotension, la bradycardie et l'asystole. Parmi les cas rapportés, les dysrythmies étaient la complication la plus répandue et englobaient des bradyarythmies, des tachyarythmies à complexes étroits et larges, une ectopie ventriculaire, et des changements au niveau du segment ST. ${ }^{9}$ Il est à noter que dans $12 \%$ des cas rapportés, la présentation initiale était l'asystole.

\section{Rapport défaillance cardiovasculaire/SNC}

Le rapport défaillance cardiovasculaire/SNC (DCV/SNC) est le rapport de la dose médicamenteuse nécessaire pour provoquer une défaillance catastrophique du SCV à la dose médicamenteuse nécessaire pour provoquer des convulsions. Parmi les AL couramment utilisés, la bupivacaïne racémique affiche le rapport DCV/SNC le plus bas, suivie par la lévobupivacaïne, la ropivacaïne et la lidocaïne. ${ }^{11}$ Cette observation s'explique par le fait que la bupivacaïne a une plus grande affinité pour les canaux sodiques, potassiques et calciques myocardiques que la lidocaïne, la lévobupivacaïne et la ropivacaïne. ${ }^{8}$ Un faible rapport DCV/SNC est associé à une plus grande cardiotoxicité. À l'inverse, les AL possédant des rapports DCV/SNC plus élevés offrent, en théorie, une plus grande marge de sécurité, étant donné que la survenue plus précoce de convulsions facilite l'identification rapide d'une TSAL et une intervention précoce, ce qui permet de prévenir la progression des complications au niveau du SCV jusqu'à la défaillance circulatoire. Toutefois, il est important de garder à l'esprit que la toxicité au niveau du SCV peut survenir sans être précédée de caractéristiques cliniques de toxicité au niveau du SNC et ce, indépendamment de l'agent utilisé. ${ }^{9}$

Présentation clinique et moment d'apparition

La majorité des cas de TSAL surviennent dans les minutes suivant l'injection d'AL et se présentent sous forme de signes au niveau du SNC, lesquels pourraient - ou non - être accompagnés de changements au niveau du SCV. ${ }^{9,12}$ Il faut souligner que la présentation est souvent atypique, tant en ce qui touche à son moment d'apparition qu'à ses manifestations cliniques. L'apparition de symptômes peut être retardée jusqu'à 60 min après l'injection d'un bolus, et les signes de toxicité au niveau du SCV peuvent survenir en l'absence de symptômes au niveau du SNC. ${ }^{9}$ Ce type de présentation semble être plus fréquent chez les patients sous sédation profonde ou sous anesthésie générale. 
La condition sine qua non de TSAL est une concentration plasmatique d'AL élevée, et celle-ci peut survenir de trois façons: une injection intra-artérielle accidentelle, une injection intraveineuse, ou une absorption systémique. Chacun de ces scénarios suit un déroulement caractéristique.

La toxicité systémique des anesthésiques locaux provoquée par une injection intra-artérielle survient en général pendant la réalisation de blocs nerveux au niveau de la tête et du cou (par ex., blocs du ganglion stellaire, interscalénique, du plexus cervical profond), au cours desquels l'AL est accidentellement injecté dans une artère alimentant le cerveau. Les symptômes au niveau du système nerveux central surviennent très rapidement, souvent sous forme de convulsions. ${ }^{12}$ La rapidité d'apparition des symptômes signifie toutefois aussi que les doses injectées sont en général plus faibles; par conséquent, la progression jusqu'à une défaillance du SCV est peu fréquente. La récupération est tout aussi rapide, étant donné que l'AL est rapidement redistribué hors de la circulation cérébrale.

L'injection intraveineuse accidentelle d'AL peut survenir au cours de la réalisation de n'importe quelle technique d'anesthésie régionale, mais son évolution en TSAL n'a tendance à survenir que lorsque des volumes plus importants ( $>5-10 \mathrm{~mL}$ ) sont injectés. Les symptômes surviennent en général au cours des cinq premières minutes $^{9}$ et peuvent rapidement s'aggraver si l'on ne prend pas de mesures adaptées.

La toxicité systémique des anesthésiques locaux résultant de l'absorption systémique d'AL est caractérisée par une présentation tardive (20-30 min ou plus après l'injection du bolus) ${ }^{12-14}$ et survient en général lorsqu'une dose relativement élevée d'AL a été administrée en présence d'autres facteurs de risque. La toxicité systémique des anesthésiques locaux peut également survenir dans le cadre d'une perfusion continue d'AL, dans quel cas son apparition peut survenir des heures, voire des jours après l'amorce de la perfusion. ${ }^{9}$ Les symptômes peuvent durer jusqu'à ce que le métabolisme du médicament réduise les concentrations plasmatiques à un niveau inférieur au seuil toxique, et un monitorage prolongé accompagné d'un traitement de soutien pourraient être nécessaires.

\section{Facteurs de risque de TSAL}

Les facteurs de risque de TSAL peuvent généralement être divisés entre ceux qui augmentent la concentration plasmatique pour une dose donnée d'AL et ceux qui augmentent la susceptibilité d'un patient individuel aux effets physiopathologiques des AL. Ces facteurs de risque comprennent les propriétés physicochimiques du médicament, la dynamique d'administration et les facteurs propres au patient. Il faut envisager de réduire la dose si l'un de ces facteurs de risque est présent.
Considérations liées à l’âge

La concentration plasmatique de la glycoprotéine $\alpha_{1}$-acide, une protéine de liaison, est considérablement réduite à la naissance, ce qui augmente la fraction plasmatique libre des AL. Les systèmes enzymatiques hépatiques sont également immatures; par conséquent, les doses d'AL devraient être réduites de $15 \%$ chez les nourrissons de moins de quatre mois. ${ }^{15}$

Bien que les concentrations plasmatiques maximales et la liaison protéique demeurent relativement inchangées chez les patients âgés, l'élimination des AL est réduite ${ }^{16}$ en raison en partie d'une réduction de la perfusion des organes et de la fonction métabolique. Les maladies dégénératives et autres comorbidités sont aussi plus prévalentes chez les patients âgés, ce qui peut augmenter leur susceptibilité aux effets systémiques des AL. En outre, les changements électrophysiologiques liés à l'âge rendent leur système nerveux périphérique plus sensible aux effets des $\mathrm{AL},{ }^{17}$ c'est pourquoi il faut envisager une réduction de 10-20\% de la dose.

\section{Dysfonction rénale}

La pharmacocinétique des $\mathrm{AL}$ amides tels que la bupivacaïne et la ropivacaïne n'est pas tellement affectée par les changements au niveau de la fonction rénale. ${ }^{18,19}$ Bien que des concentrations plasmatiques totales plus élevées d'AL aient été observées chez des patients atteints d'insuffisance rénale terminale (attribuées à une circulation hyperdynamique et à une extraction accrue d'AL du site d'injection), elles sont contrebalancées par une augmentation de la glycoprotéine $\alpha_{1}$-acide. Dès lors, les concentrations plasmatiques libres sont majoritairement inchangées. ${ }^{20}$ Par conséquent, une réduction systématique de la dose n'est en général pas nécessaire, sauf chez les patients urémiques atteints d'acidose métabolique, lesquels pourraient être plus susceptibles à une TSAL.

\section{Maladies cardiaques}

Plusieurs facteurs contribuent à un risque accru de TSAL chez les patients atteints de dysfonction cardiaque grave, notamment une réduction de la perfusion hépatique et de l'élimination médicamenteuse ainsi que des concentrations tissulaires élevées d'AL en raison d'un temps de circulation prolongé. Si la perfusion tissulaire est conservée, il n'est pas nécessaire d'ajuster la dose dans les cas d'insuffisance cardiaque légère à modérée, mais un ajustement est recommandé en cas d'insuffisance cardiaque avancée. ${ }^{16}$ Les troubles de conduction pourraient prédisposer à une toxicité au niveau du SCV; par conséquent, on préconise l'utilisation d'AL moins cardiotoxiques, comme par 
exemple la ropivacaïne ou la lévobupivacaïne, en conjonction avec une posologie judicieuse.

\section{Dysfonction hépatique}

Chez les patients atteints de dysfonction hépatique, l'élimination réduite des AL est contrecarrée par un volume accru de distribution, et leurs concentrations plasmatiques sont semblables à celles observées auprès de patients sains. ${ }^{16}$ La synthèse de la glycoprotéine $\alpha_{1}$-acide est maintenue même lors de maladie hépatique terminale, ce qui procure une zone tampon de sécurité supplémentaire. Pour cette raison, les patients souffrant d'insuffisance hépatique isolée ne nécessitent pas d'ajustement de dose pour les blocs réalisés par injection unique. Ceci étant dit, l'élimination réduite dont ils sont les victimes doit être prise en considération chez les patients atteints de dysfonction hépatique avancée - surtout si celle-ci est compliquée par d'autres défaillances systémiques - et qui reçoivent une perfusion d'AL continue ou des injections de bolus à répétition; dans de tels cas, les doses doivent être ajustées en conséquence.

\section{Grossesse}

On privilégie l'anesthésie régionale plutôt que l'anesthésie générale chez les patientes enceintes en raison de risques potentiels d'intubation difficile, d'aspiration gastrique, de compression aorto-cavale, et d'anomalies théoriques du développement fœtal durant le premier trimestre; ${ }^{21}$ toutefois, en raison des changements physiologiques progressifs qu'elles subissent, ces patientes courent un risque plus élevé de souffrir de TSAL. L'augmentation du débit cardiaque, à partir du deuxième trimestre, pourrait augmenter l'absorption de l'AL et donc sa concentration plasmatique. $^{22}$ L'engorgement veineux péridural pourrait augmenter l'absorption d'AL, ainsi que le risque de migration du cathéter dans une veine. La liaison protéique diminue progressivement tout au long de la grossesse, atteignant son nadir au terme, ce qui augmente la concentration d'AL plasmatique libre. ${ }^{23}$ Les changements biochimiques et hormonaux qui surviennent durant la grossesse augmentent en outre la sensibilité neuronale aux $\mathrm{AL}$ et pourraient également réduire le seuil de convulsions provoquées par la TSAL. ${ }^{24}$ Par conséquent, il est prudent de limiter les doses d'AL pour les blocs neuraxiaux périphériques et centraux chez les parturientes, particulièrement celles à des stades plus avancés de leur grossesse. ${ }^{16}$

Site du bloc et technique d'injection

Dans les sites d'injection très vascularisés, le risque d'injection intravasculaire accidentelle directe d'AL et d'absorption systémique accrue est plus grand. Ces sites comprennent l'espace intercostal, le compartiment du psoas (plexus lombaire) et la région fessière (nerf sciatique proximal). Les blocs réalisés dans ces zones ont été associés à une TSAL malgré le respect de recommandations de doses maximales.

Ces dernières années, les blocs impliquant le dépôt de doses importantes d'AL dans les plans intermusculaires (par ex., les TAP) ainsi qu'au site de l'incision chirurgicale (par ex., analgésie par infiltration locale) sont de plus en plus répandus. On a rapporté des cas de TSAL après des TAP $^{13,25}$ et il semble que les doses utilisées dans la pratique clinique produisent des concentrations plasmatiques maximales qui dépassent souvent les seuils

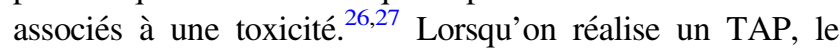
risque de TSAL est considérable pour plusieurs raisons : d'importants volumes d'injection $(\geq 20 \mathrm{~mL}$ par côté chez l'adulte) sont utilisés afin de garantir une bonne diffusion de l'AL, on réalise souvent des blocs bilatéraux afin de couvrir des incisions médianes, et le muscle transverse de l'abdomen contient un vaste réseau de vaisseaux. En outre, on réalise souvent ces blocs pour l'analgésie après un accouchement par césarienne et, comme mentionné plus haut, ces patientes pourraient être plus susceptibles à une TSAL.

Bien que les études pharmacocinétiques portant sur l'analgésie par infiltration locale dans les arthroplasties totales du genou ${ }^{28,29}$ et de la hanche ${ }^{30,31}$ aient démontré que les concentrations plasmatiques libres de ropivacaïne étaient inférieures aux seuils moyens de toxicité établis chez des volontaires sains, un nombre significatif de patients étudiés ont tout de même manifesté des symptômes mineurs de TSAL. Une présentation de cas récente a décrit une TSAL significative et prolongée suite à une analgésie par infiltration locale, ce qui souligne le risque couru par ces patients, lesquels sont souvent plus âgés et affectés par de multiples comorbidités. ${ }^{14}$

\section{Prévention de la TSAL}

Posologie adaptée de l'anesthésique local

Du point de vue de la sécurité du patient, la dose appropriée (masse) d'AL est la plus faible dose qui permette d'obtenir l'étendue et la durée désirées d'anesthésie ou d'analgésie. ${ }^{4}$ Cependant, la dose permissible maximale, quel que soit le patient, est plus difficile à déterminer. Pour une dose donnée, les concentrations plasmatiques et au site d'action varieront selon le site d'administration ainsi que selon des différences pharmacocinétiques individuelles. Bien que des concentrations plasmatiques spécifiques soient souvent citées comme seuils de TSAL, ${ }^{32}$ ces chiffres ne sont qu'une moyenne de distribution normale chez des volontaires sains 
Tableau 1 Recommandations posologiques suggérées pour les anesthésiques locaux fréquemment utilisés

\begin{tabular}{|c|c|c|c|c|}
\hline \multirow[t]{2}{*}{ Agent } & \multicolumn{2}{|l|}{ Solution simple } & \multicolumn{2}{|l|}{ Avec épinéphrine } \\
\hline & Dose maximale $\left(\mathrm{mg} \cdot \mathrm{kg}^{-1}\right)$ & Dose maximale (mg) & Dose maximale $\left(\mathrm{mg} \cdot \mathrm{kg}^{-1}\right)$ & Dose maximale $(\mathrm{mg})$ \\
\hline Lidocaïne & $5 \mathrm{mg} \cdot \mathrm{kg}^{-1}$ & $350 \mathrm{mg}$ & $7 \mathrm{mg} \cdot \mathrm{kg}^{-1}$ & $500 \mathrm{mg}$ \\
\hline Mépivacaïne & $5 \mathrm{mg} \cdot \mathrm{kg}^{-1}$ & $350 \mathrm{mg}$ & $7 \mathrm{mg} \cdot \mathrm{kg}^{-1}$ & $500 \mathrm{mg}$ \\
\hline Bupivacaïne & $2 \mathrm{mg} \cdot \mathrm{kg}^{-1}$ & $175 \mathrm{mg}$ & $3 \mathrm{mg} \cdot \mathrm{kg}^{-1}$ & $225 \mathrm{mg}$ \\
\hline Lévobupivacaïne & $2 \mathrm{mg} \cdot \mathrm{kg}^{-1}$ & $200 \mathrm{mg}$ & $3 \mathrm{mg} \cdot \mathrm{kg}^{-1}$ & $225 \mathrm{mg}$ \\
\hline Ropivacaïne & $3 \mathrm{mg} \cdot \mathrm{kg}^{-1}$ & $200 \mathrm{mg}$ & $3 \mathrm{mg} \cdot \mathrm{kg}^{-1}$ & $250 \mathrm{mg}$ \\
\hline
\end{tabular}

Adapté de:

1. Berde CB, Strichartz, GR. Local anesthetics. In: Miller RD (Ed.). Miller's Anesthesia, 8th ed. Philadelphia: Elsevier; $2015: 1043$

2. Dadure C, Sola C, Dalens B, Capdevila X. Regional anesthesia in children. In: Miller RD (Ed.). Miller's Anesthesia, 8th ed. Philadelphia: Elsevier; 2015: 2718

3. American Academy of Pediatrics; American Academy of Pediatric Dentistry, Cote CJ, Wilson S; Work Group on Sedation. Guidelines for monitoring and management of pediatric patients during and after sedation for diagnostic and therapeutic procedures: an update. Pediatrics 2006; 118: $2587-602$

et ne tiennent pas compte de la variabilité interindividuelle en matière de susceptibilité à la TSAL.

Ces observations ont remis en question la pertinence des recommandations en matière de doses maximales ${ }^{16}$ et de dosage par kilogramme chez l'adulte. ${ }^{33}$ Quoi qu'il en soit, ces recommandations sont néanmoins utiles et ne devraient pas être dépassées sans avoir bien soupesé les avantages et les risques, particulièrement chez les patients de faible poids (voir Tableau 1). Mais, plus important encore, il faut garder à l'esprit que la TSAL peut survenir malgré le respect de ces limites. Chez les patients en surpoids, le dosage doit se fonder sur le poids maigre plutôt que sur la masse corporelle absolue et doit être ajusté à la baisse lorsque possible dans le cas de techniques ou de patients à risque plus élevé. Si l'on a recours à des combinaisons d'AL, le risque de TSAL doit être considéré comme étant additif et la dose de chaque agent doit par conséquent être réduite.

\section{Utilisation d'AL plus sécuritaires}

La ropivacaïne et la lévobupivacaïne semblent être moins toxiques que la bupivacaïne racémique; il est par conséquent logique de les préférer lorsqu'on souhaite utiliser un AL à action prolongée. En revanche, cela ne nous dispense pas de prendre des précautions supplémentaires, étant donné que ces deux agents peuvent tout de même provoquer une importante TSAL. ${ }^{9,13,26,34}$

Détection précoce de la ponction vasculaire et de l'injection intravasculaire

\section{Aspiration avant l'injection}

Une aspiration devrait toujours être réalisée avant d'injecter un AL : il s'agit d'un geste simple qui permet souvent de détecter une ponction vasculaire accidentelle. On observe toutefois un taux considérable de faux négatifs, tant avec les cathéters périduraux ${ }^{35}$ qu'avec les blocs nerveux périphériques. ${ }^{36}$

\section{Dosage fractionné avec marqueurs d'injection intravasculaire}

Les anesthésiques locaux devraient être injectés en incréments de 3-5 mL, et les injections devraient être séparées par au moins un temps de circulation (30-45 sec). En théorie, cela permet de détecter l'injection intravasculaire avant qu'une dose excessive d'AL n'ait été administrée. Le marqueur le plus utilisé est l'épinéphrine. Une dose intravasculaire de 15 $\mu \mathrm{g}$ d'épinéphrine ( $3 \mathrm{~mL}$ d'une solution 1:200 000) produira en général une augmentation de la fréquence cardiaque $\geq 10$ battements ou une augmentation de la tension artérielle systolique $\geq 15 \mathrm{mmHg}$. La réponse hémodynamique est cependant atténuée chez les patients prenant des bêtabloquants, ${ }^{37}$ chez les patients âgés et ceux qui sont sous sédation ou sous anesthésie générale. ${ }^{38}$ L'utilisation d'épinéphrine dans l'analgésie péridurale pour le travail obstétrical est également controversée en raison de la possibilité de résultats faux positifs provenant de contractions utérines simultanées et d'une réponse accrue de la fréquence cardiaque, ainsi que d'inquiétudes quant à une exacerbation possible de l'hypertension dans les cas de préeclampsie. ${ }^{38}$ Bien qu' une tendance récente vise à éviter cet agent dans les blocs nerveux périphériques en raison d'une crainte que la vasoconstriction locale exacerbe sa neurotoxicité, les données probantes cliniques font encore défaut. Enfin, l'épinéphrine a l'avantage supplémentaire de réduire les concentrations plasmatiques maximales d'AL, ${ }^{39}$ ce qui, tout bien considéré, rend les avantages de l'épinéphrine bien plus importants que ses limites et risques potentiels. 
Tableau 2 Prise en charge de la toxicité systémique des anesthésiques locaux (TSAL)

\section{PRÉPARATION}

- Accès facile à une Trousse de toxicité systémique des anesthésiques locaux; comme contenu, on suggère une « checklist » imprimée pour la prise en charge de la TSAL, ${ }^{5,41}$ un sac d'émulsion lipidique $20 \%$, des tubulures, seringues et aiguilles intraveineuses.

\section{PRÉVENTION}

- Dosage d'AL adapté

- Utilisation d'AL moins cardiotoxiques

- Aspiration avant l'injection

- Dosage fractionné

- Utilisation de marqueurs d'injection intravasculaire

- Blocs nerveux périphériques échoguidés

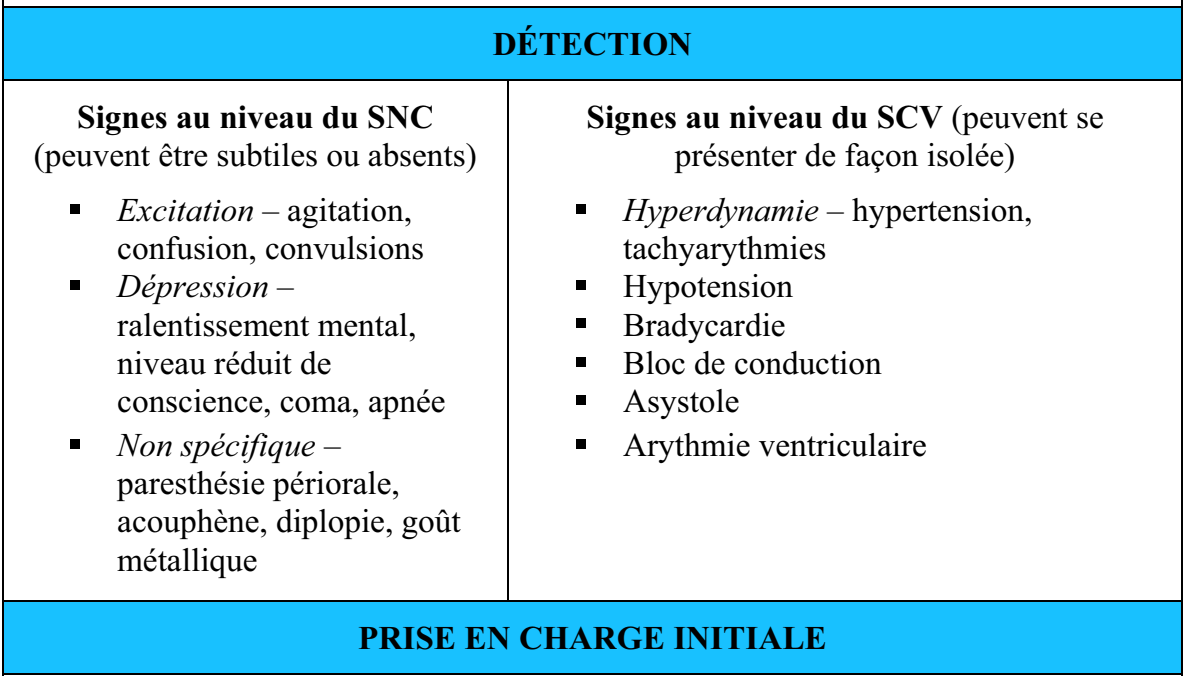

- Cesser l'injection d'AL

- Appeler à l'aide et demander la Trousse de toxicité systémique des anesthésiques locaux

- Maintenir les voies aériennes et les sécuriser au besoin; ventiler avec $100 \%$ d'oxygène

- Confirmer ou établir l'accès intraveineux

- Interrompre ou supprimer les convulsions à l'aide de benzodiazépines, de propofol (s'il n'y a pas d'instabilité cardiovasculaire) ou de thiopental

- Envisager une émulsion lipidique injectable si les symptômes au niveau du SNC persistent ou recommencent

- Envisager une prise de sang pour mesurer la concentration plasmatique d'AL si cela ne provoque pas de retard dans le traitement définitif 
Tableau 2 suite

\begin{tabular}{|c|}
\hline TRAITEMENT \\
\hline $\begin{array}{l}\text { Arythmies cardiaques } \\
\text { - En cas d'arrêt circulatoire, suivre les algorithmes de soins avancés de } \\
\text { réanimation cardiorespiratoire (ACLS) en y apportant les modifications } \\
\text { énumérées ci-dessous. } \\
\text { - L'oxygénation, la ventilation et les compressions cardiaques sont absolument } \\
\text { cruciales } \\
\text { - Administrer une émulsion lipidique injectable dès que possible } \\
\text { - Alerter le centre de circulation extracorporelle le plus proche } \\
\text { - Réduire la dose d'épinéphrine à }<1 \mu \mathrm{g} \cdot \mathrm{kg}^{-1} \text { et, lorsque possible, } \\
\text { l'administration devrait être précédée de l'amorce d'un traitement par } \\
\text { émulsion lipidique injectable } \\
\text { - L'amiodarone peut être utilisée mais éviter les bêtabloquants, les inhibiteurs } \\
\text { - calciques, les inhibiteurs sodiques ou la vasopressine } \\
\text { Envisager une circulation extracorporelle lors d'arrêt cardiaque réfractaire } \\
\text { prolongé, particulièrement si des AL à action prolongée ont été administrés }\end{array}$ \\
\hline $\begin{array}{l}\text { Traitement par émulsion lipidique intraveineuse } 20 \% \\
\text { [Les valeurs entre crochets sont pour un adulte de } 70 \mathrm{~kg}] \\
\text { - Bolus de } 1,5 \mathrm{~mL} \cdot \mathrm{kg}^{-1} \text { sur } 1 \mathrm{~min}[100 \mathrm{~mL}] \\
\text { - Perfusion continue de } 15 \mathrm{~mL} \cdot \mathrm{kg}^{-1} \cdot \mathrm{h}^{-1}\left[1000 \mathrm{~mL} \cdot h^{-1}\right] \\
\text { Si l'instabilité cardiovasculaire persiste ou se détériore après } 5 \text { minutes : } \\
\text { - Répéter le même bolus jusqu'à deux fois supplémentaires } \\
\text { - Doubler le taux de perfusion à } 30 \mathrm{~mL} \cdot \mathrm{kg}^{-1} \cdot \mathrm{h}^{-1}\left[2000 \mathrm{~mL} \cdot \mathrm{h}^{-1}\right] \\
\text { - Continuer la perfusion pendant } 10 \mathrm{~min} \text { après le rétablissement de la stabilité } \\
\text { - } \text { cardiovasculaire }\end{array}$ \\
\hline SUIVI \\
\hline $\begin{array}{l}\text { - Transfert vers une zone clinique disposant du monitorage, du matériel et du } \\
\text { - Exsonnel adaptés pour un monitorage }>12 \mathrm{~h} \\
\text { - Examen clinique régulier afin d'exclure la pancréatite, notamment par examen } \\
\text { en série de l'amylase ou de la lipase pendant } 2 \text { jours } \\
\text { - Rapporter les cas et l'utilisation de l'ELI sur www.lipidrescue.org }\end{array}$ \\
\hline
\end{tabular}

Adapté de :

1.Liste de contrôle pour le traitement de la toxicité systémique des anesthésiques locaux de l'American Society of Regional Anesthesia and Pain Medicine. ${ }^{41}$

2.Directive de sécurité de l'Association of Anaesthetists of Great Britain and Ireland : « Management of severe local anaesthetic toxicity » (La prise en charge d'une toxicité anesthésique locale grave). ${ }^{5}$

$\mathrm{SNC}=$ système nerveux central; $\mathrm{SCV}=$ système cardiovasculaire $; \mathrm{LA}=$ anesthésique local

Les blocs nerveux périphériques échoguidés

Des données probantes récentes indiquent que l'incidence de TSAL est plus basse après un bloc nerveux périphérique réalisé sous échoguidage que lors de techniques réalisées sans échoguidage. ${ }^{3}$ Cela peut s'expliquer par (1) la réduction des doses nécessaires
d'AL, (2) la capacité de voir les vaisseaux à risque de ponction, (3) le fractionnement et les pauses inhérents qui accompagnent l'approche recommandée, soit d'évaluer visuellement la diffusion de petits bolus d'AL (hydrolocalisation), et (4) la détection d'une éventuelle injection intravasculaire en l'absence de diffusion visible. 


\section{Prise en charge de la TSAL}

\section{Préparation et vigilance}

Un accès intraveineux, de l'oxygène et un monitorage standard (oxymétrie de pouls, tension artérielle, échocardiogramme) devraient être installés de façon systématique chez tous les patients recevant des doses importantes d'AL. Du matériel et des médicaments de réanimation doivent être disponibles, de même qu'une liste de contrôle imprimée (« checklist») de la prise en charge de la TSAL étape par étape. ${ }^{41}$ L'assemblage d'une « trousse de TSAL » est encouragé dans les centres qui administrent régulièrement d'importantes doses d'AL (voir Tableau 2). ${ }^{41}$

Maintenir les voies aériennes, l'oxygénation et la ventilation

Il est crucial d'éviter l'hypoxémie et l'acidose (métabolique ou respiratoire) lors de la prise en charge d'une TSAL. Des études de laboratoire ont démontré que ces deux facteurs exacerbaient la TSAL et que, s'ils persistent, ils pourraient favoriser une progression de la condition vers un arrêt cardiaque et entraver le retour à une circulation spontanée. Il convient toutefois de souligner que l'hyperventilation et l'alcalose respiratoire subséquente pourraient également être néfastes et devraient donc être évitées.

\section{Interrompre et supprimer les convulsions}

Les convulsions prolongées exacerbent l'acidose métabolique et doivent être traitées dans les plus brefs délais. Les benzodiazépines sont le traitement de première ligne recommandé, étant donné qu'elles ne provoquent en général pas d'instabilité cardiovasculaire excessive. ${ }^{43} \mathrm{Le}$ propofol, en revanche, ne devrait être utilisé que si les benzodiazépines ne sont pas disponibles ou si les convulsions ne répondent pas au traitement. En effet, il a été démontré que cet agent pouvait exacerber la cardiotoxicité subclinique et favoriser la progression à un collapsus circulatoire, particulièrement si des doses importantes sont administrées. ${ }^{43}$ On a proposé d'utiliser de la succinylcholine à faible dose lors de convulsions réfractaires afin de réduire l'acidose métabolique provoquée par les contractions musculaires, ${ }^{4}$ mais il faut garder à l'esprit que cet agent ne fera que masquer l'activité convulsive, et non la faire cesser.

Le maintien de la perfusion tissulaire

En cas d'arrêt cardiaque, il faut suivre les algorithmes normalisés de soins avancés en réanimation cardiovasculaire (ACLS) pour effectuer la réanimation cardiorespiratoire, y compris les indications pour la cardioversion et le déplacement de l'utérus chez les patientes enceintes. Il faut amorcer les compressions thoraciques immédiatement et les maintenir jusqu'au rétablissement de la circulation spontanée. Les AL n'endommagent pas directement les myocytes cardiaques, et tant qu'il n'y a pas d'hypoxie tissulaire, la récupération complète est possible et ce, même après une réanimation cardiorespiratoire prolongée. Le maintien d'une circulation adéquate accélère également le processus de récupération en facilitant la diffusion de l'AL hors des tissus cardiaques. En l'absence d'une récupération rapide à la suite des mesures d'ACLS et d'un traitement par émulsion lipidique injectable (ELI), il faut rapidement envisager la circulation extracorporelle (CEC) afin d'assurer une assistance circulatoire adéquate. ${ }^{4}$ Cette mesure devrait être envisagée tôt dans la prise en charge, étant donné qu'elle peut prendre un certain temps à être mise en place, même dans un centre hospitalier tertiaire. ${ }^{44}$

Utilisation judicieuse des vasopresseurs et des médicaments antiarythmiques

Comme cela a été souligné plus haut, lors d'un arrêt cardiaque, l'emphase doit être mise sur le maintien de la circulation à l'aide de compressions thoraciques ou de circulation extracorporelle, en attendant que l'AL soit éliminé ou que ses effets soient neutralisés par ELI. L'épinéphrine peut être utilisée pour augmenter la résistance vasculaire systémique et la contractilité myocardique, mais elle doit être administrée en petites doses $<1 \mu \mathrm{g} \cdot \mathrm{kg}^{-1}{ }^{4}$ Des études animales ont démontré que des doses plus importantes favorisaient les tachyarythmies et étaient associées à un pronostic plus sombre comparativement à un traitement par ELI. ${ }^{43}$ La vasopressine a également été associée à des complications pulmonaires et métaboliques dans des modèles animaux de TSAL et devrait, dans la mesure du possible, être évitée. ${ }^{4}$

Parmi les divers médicaments antiarythmiques mentionnés dans les algorithmes d' ACLS, seule l'amiodarone est recommandée en cas de TSAL. La lidocaïne et les autres inhibiteurs sodiques (par ex., le procaïnamide) devraient être évités, et les bêtabloquants et les inhibiteurs calciques ne devraient pas être administrés en raison de leurs effets cardiodépresseurs et vasodilatateurs.

Le traitement par émulsion lipidique intraveineuse

Ce traitement constitue probablement le progrès le plus important en matière de prise en charge de la TSAL. Il est également utilisé pour la prise en charge d'un éventail 
toujours croissant de syndromes toxicologiques. ${ }^{45}$ Les mécanismes de fonctionnement de ce traitement incluent (1) son effet « d'éponge » lipidique intravasculaire, qui lie et désactive une importante quantité de molécules lipophiles d'AL, (2) la promotion du métabolisme des acides gras mitochondriaux et de l'ATP synthase dans les cellules myocardiques, et (3) un effet inotrope direct en raison de l'augmentation du contenu calcique intracellulaire myocardique. À ce jour, les mécanismes ci-dessus ne sont pas encore complètement élucidés.

À l'heure actuelle, il n'y a pas suffisamment de données probantes pour conclure qu'une préparation d'ELI en particulier est supérieure aux autres, mais la plupart des recherches cliniques rapportées utilisent une émulsion composée de triglycérides à longue chaîne à base de soya, soit l'Intralipid ${ }^{\circledR} 20 \%$ (Fresenius Kabi, AG, Bad Homburg, Allemagne). Le propofol ne constitue pas une alternative adaptée au traitement par ELI.

L'émulsion lipidique injectable possède un indice thérapeutique élevé, ${ }^{46}$ et il faut envisager une administration précoce lorsqu' on soupçonne une TSAL, ${ }^{4}$ à la fois pour aider à neutraliser les symptômes au niveau du SNC que pour cesser la progression vers une défaillance cardiovasculaire. L'ELI ne remplace toutefois pas une réanimation cardiorespiratoire efficace, laquelle est essentielle pour assurer un pronostic optimal lors d'un arrêt cardiaque associé à une TSAL.

Les recommandations posologiques actuelles se fondent sur la masse maigre et sont résumées dans le Tableau 2. Pour un adulte moyen de $70 \mathrm{~kg}$, la dose initiale est facile à garder en tête, soit un bolus de $100 \mathrm{~mL}$ d'ELI $20 \%$ suivi d'une perfusion de $1000 \mathrm{~mL} \cdot \mathrm{hr}^{-1}$. Si l'instabilité hémodynamique persiste, deux bolus supplémentaires peuvent être administrés et le taux de perfusion doublé, pour atteindre une dose maximale recommandée de 10 $\mathrm{mL} \cdot \mathrm{kg}^{-1}$ au cours des premières $30 \mathrm{~min}$.

La plupart des inquiétudes concernant les effets secondaires néfastes de l'ELI se fondent sur les risques liés à une administration prolongée, ${ }^{46}$ bien que des réactions de thrombophlébite périphérique et d'hypersensibilité soient possibles lors d'une administration isolée. Les comptes rendus cliniques publiés à ce jour indiquent qu'un traitement par ELI pour une TSAL est très sécuritaire, mais il est recommandé d'effectuer des mesures en série de l'amylase ou de la lipase pour une durée allant jusqu'à $48 \mathrm{~h}$ afin d'exclure l'apparition d'une pancréatite. ${ }^{5}$ Chez les patients allergiques aux œufs ou au soya, les avantages potentiels de l'ELI pour neutraliser une défaillance cardiovasculaire sont probablement supérieurs au risque théorique d'une réaction allergique. Il faut également souligner que la lipémie subséquente peut interférer avec des mesures d'électrolytes ou de l'hémoglobine réalisées en laboratoire.
Prise en charge après l'événement

La décision de poursuivre la chirurgie après la récupération suite à un épisode de TSAL doit être prise au cas par cas en se fondant sur l'avis de tous les intervenants. Quelle que soit la décision, il faut surveiller les patients pour prévenir toute récurrence des symptômes, idéalement pour une durée supérieure à $12 \mathrm{~h}^{4,9,14}$ En cas d'administration d'ELI, les cas doivent être rapportés au registre prévu à cet effet au www.lipidrescue.org.

\section{Cas clinique}

Une patiente de 88 ans et pesant $40 \mathrm{~kg}$ se présente avec une fracture intertrochantérienne du col du fémur. On prévoit de lui installer une vis dynamique de hanche. Elle a des antécédents d'hypertension, d'insuffisance cardiaque légère, et d'hypercholestérolémie. Elle prend quotidiennement $5 \mathrm{mg}$ de bisoprolol, $20 \mathrm{mg}$ d'atorvastatine et $81 \mathrm{mg}$ d'acide acétylsalicylique. En salle d'opération, elle est alerte et orientée. On amorce le monitorage standard avec des saturations de $98 \%$ sur $6 \mathrm{~L} \cdot \mathrm{min}^{-1}$ d'oxygène par masque facial, une tension artérielle de $152 / 89 \mathrm{mmHg}$, et une fréquence cardiaque de 66 battements. $\mathrm{min}^{-1}$.

Vous réalisez un bloc du fascia ilio-psoïque par repère anatomique avec $30 \mathrm{~mL}$ de bupivacaïne $0,5 \%$ et 2,5 $\mu \mathrm{g} \cdot \mathrm{mL}^{-1}$ d'épinéphrine, suivi par une rachianesthésie à base de $10 \mathrm{mg}$ de bupivacaïne hyperbare et de $15 \mu \mathrm{g}$ de fentanyl.

Après avoir réalisé les blocs, les saturations de la patiente sont à $98 \%$ sous oxygène; sa tension artérielle est de $136 / 82 \mathrm{mmHg}$ et sa fréquence cardiaque de 65 battements $\cdot \min ^{-1}$.

\section{Directives pour compléter le module de développement professionnel continu (DPC):}

1. Lisez cet article et les références en gras.

2. Allez à: http://www.cas.ca/Members/CPD-Online et choisissez le module actuel : La toxicité systémique des anesthésiques locaux.

3. Répondez aux questions à choix de réponses concernant le cas clinique.

4. Une fois que vous avez saisi toutes vos réponses, vous aurez accès aux explications d'experts pour tous les choix possibles.

5. Les participants peuvent réclamer un maximum de quatre heures de DPC pour un total de 12 crédits sous la Section 3 du programme de DPC du Collège royal des médecins et chirurgiens du Canada. 
Conflicts of interest None declared.

Funding sources Dr. Ki Jinn Chin is supported by a Merit Award from the Department of Anesthesia, University of Toronto.

\section{Conflit d'intérêt Aucun.}

Sources de financement $\mathrm{Dr}$ Ki Jinn Chin est récipiendaire d'une prime de mérite du département d'anesthésie de l'Université de Toronto.

\section{References}

1. Auroy Y, Benhamou D, Bargues L, Ecoffey C, et al. Major complications of regional anesthesia in France: The SOS Regional Anesthesia Hotline Service. Anesthesiology 2002; 97: 1274-80.

2. Brown DL, Ransom DM, Hall JA, Leicht CH, Schroeder DR, Offord KP. Regional anesthesia and local anesthetic-induced systemic toxicity: seizure frequency and accompanying cardiovascular changes. Anesth Analg 1995; 81: 321-8.

3. Barrington MJ, Kluger R. Ultrasound guidance reduces the risk of local anesthetic systemic toxicity following peripheral nerve blockade. Reg Anesth Pain Med 2013; 38: 289-97.

4. Neal JM, Bernards CM, Butterworth JF 4th, et al. ASRA practice advisory on local anesthetic systemic toxicity. Reg Anesth Pain Med 2010; 35: 152-61.

5. The Association of Anaesthetists of Great Britain and Ireland. AAGBI Safety Guideline: Management of Severe Local Anaesthetic Toxicity 2010; Available from URL: http://www. aagbi.org/sites/default/files/la_toxicity_2010_0.pdf. (Accessed September 2015)

6. Dillane D, Finucane BT. Local anesthetic systemic toxicity. Can J Anesth 2010; 57: 368-80.

7. Becker DE, Reed KL. Local anesthetics: review of pharmacological considerations. Anesth Prog 2012; 59: 90-101.

8. Zink W, Graf BM. The toxicity of local anesthetics: the place of ropivacaine and levobupivacaine. Curr Opin Anaesthesiol 2008; 21: $645-50$

9. Di Gregorio G, Neal JM, Rosenquist RW, Weinberg GL. Clinical presentation of local anesthetic systemic toxicity: a review of published cases, 1979 to 2009. Reg Anesth Pain Med 2010; 35: 181-7.

10. Watanabe $Y$, Dohi $S$, Iida $H$, Ishiyama $T$. The effects of bupivacaine and ropivacaine on baroreflex sensitivity with or without respiratory acidosis and alkalosis in rats. Anesth Analg 1997; 84: 398-404.

11. Groban L. Central nervous system and cardiac effects from longacting amide local anesthetic toxicity in the intact animal model. Reg Anesth Pain Med 2003; 28: 3-11.

12. Mulroy $M F$. Systemic toxicity and cardiotoxicity from local anesthetics: incidence and preventive measures. Reg Anesth Pain Med 2002; 27: 556-61.

13. Weiss E, Jolly $C$, Dumoulin JL, et al. Convulsions in 2 patients after bilateral ultrasound-guided transversus abdominis plane blocks for cesarean analgesia. Reg Anesth Pain Med 2014; 39: 248-51.

14. Fenten $M G$, Rohrbach A, Wymenga AB, Stienstra R. Systemic local anesthetic toxicity after local infiltration analgesia following a polyethylene tibial insert exchange: a case report. Reg Anesth Pain Med 2014; 39: 264-5.

15. Meunier JF, Goujard E, Dubousset AM, Samii K, Mazoit JX. Pharmacokinetics of bupivacaine after continuous epidural infusion in infants with and without biliary atresia. Anesthesiology 2001; 95: 87-95.

16. Rosenberg PH, Veering BT, Urmey WF. Maximum recommended doses of local anesthetics: a multifactorial concept. Reg Anesth Pain Med 2004; 29: 564-75.

17. Paqueron X, Boccara $G$, Bendahou $M$, Coriat $P$, Riou B. Brachial plexus nerve block exhibits prolonged duration in the elderly. Anesthesiology 2002; 97: 1245-9.

18. Pere PJ, Ekstrand A, Salonen M, et al. Pharmacokinetics of ropivacaine in patients with chronic renal failure. $\mathrm{Br} \mathbf{J}$ Anaesth 2011; 106: 512-21.

19. Rice AS, Pither CE, Tucker GT. Plasma concentrations of bupivacaine after supraclavicular brachial plexus blockade in patients with chronic renal failure. Anaesthesia 1991; 46: 354-7.

20. Pere P, Salonen M, Jokinen M, Rosenberg PH, Neuvonen PJ, Haasio $J$. Pharmacokinetics of ropivacaine in uremic and nonuremic patients after axillary brachial plexus block. Anesth Analg 2003; 96: 563-9.

21. Reitman E, Flood P. Anaesthetic considerations for non-obstetric surgery during pregnancy. Br J Anaesth 2011; 107(Suppl 1): i72-

22. Pihlajamaki K, Kanto J, Lindberg R, Karanko M, Kiilholma P. Extradural administration of bupivacaine: pharmacokinetics and metabolism in pregnant and non-pregnant women. $\mathrm{Br} \mathrm{J}$ Anaesth 1990; 64: 556-62.

23. Tsen LC, Tarshis J, Denson DD, Osathanondh R, Datta S, Bader $A M$. Measurements of maternal protein binding of bupivacaine throughout pregnancy. Anesth Analg 1999; 89: 965-8.

24. Santos AC, DeArmas PI. Systemic toxicity of levobupivacaine, bupivacaine, and ropivacaine during continuous intravenous infusion to nonpregnant and pregnant ewes. Anesthesiology 2001; 95: 1256-64.

25. Griffiths JD, Le NV, Grant S, Bjorksten A, Hebbard P, Royse C. Symptomatic local anaesthetic toxicity and plasma ropivacaine concentrations after transversus abdominis plane block for caesarean section. Br J Anaesth 2013; 110: 996-1000.

26. Griffiths JD, Barron FA, Grant S, Bjorksten AR, Hebbard P, Royse $C F$. Plasma ropivacaine concentrations after ultrasoundguided transversus abdominis plane block. Br J Anaesth 2010; 105: 853-6.

27. Hessian EC, Evans BE, Woods JA, Taylor DJ, Kinkel E, Bjorksten AR. Plasma ropivacaine concentrations during bilateral transversus abdominis plane infusions. $\mathrm{Br} \mathrm{J}$ Anaesth 2013; 111: 488-95.

28. Busch CA, Whitehouse MR, Shore BJ, MacDonald SJ, McCalden $R W$, Bourne RB. The efficacy of periarticular multimodal drug infiltration in total hip arthroplasty. Clin Orthop Relat Res 2010; 468: 2152-9.

29. Brydone AS, Souvatzoglou R, Abbas M, Watson DG, McDonald $D A$, Gill AM. Ropivacaine plasma levels following high-dose local infiltration analgesia for total knee arthroplasty. Anaesthesia 2015; . DOI:10.1111/anae.13017.

30. Gill AM, Scott NB, Abbas M, Watson DG, Place K, McDonald $D A$. Ropivacaine plasma levels following local infiltration analgesia for primary total hip arthroplasty. Anaesthesia 2014; 69: 368-73.

31. Affas F, Eksborg S, Wretenberg P, Olofsson C, Stiller CO. Ropivacaine pharmacokinetics after local infiltration analgesia in hip arthroplasty. Anesth Analg 2014; 119: 996-9.

32. Knudsen $K$. Beckman Suurkula M, Blomberg S, Sjovall J, Edvardsson N. Central nervous and cardiovascular effects of i.v. infusions of ropivacaine, bupivacaine and placebo in volunteers. Br J Anaesth 1997; 78: 507-14.

33. Mulroy MF, Hejtmanek MR. Prevention of local anesthetic systemic toxicity. Reg Anesth Pain Med 2010; 35: 177-80. 
34. Breslin DS, Martin G, Macleod DB. D'ercole F, Grant SA. Central nervous system toxicity following the administration of levobupivacaine for lumbar plexus block: a report of two cases. Reg Anesth Pain Med 2003; 28: 144-7.

35. Pan PH, Bogard TD, Owen MD. Incidence and characteristics of failures in obstetric neuraxial analgesia and anesthesia: a retrospective analysis of 19,259 deliveries. Int J Obstet Anesth 2004; 13: 227-33.

36. Robards $C$, Clendenen $S$, Greengrass $R$. Intravascular injection during ultrasound-guided axillary block: negative aspiration can be misleading. Anesth Analg 2008; 107: 1754-5.

37. Pong RP, Bernards CM, Hejtmanek MR, Slee AE, Batra MS. Effect of chronic $\beta$-blockade on the utility of an epinephrinecontaining test dose to detect intravascular injection in nonsedated patients. Reg Anesth Pain Med 2013; 38: 403-8.

38. Guay J. The epidural test dose: a review. Anesth Analg 2006; 102: 921-9.

39. Corvetto MA, Echevarría GC, De La Fuente $N$, Mosqueira L, Solari S, Altermatt FR. Comparison of plasma concentrations of levobupivacaine with and without epinephrine for transversus abdominis plane block. Reg Anesth Pain Med 2012; 37: 633-7.
40. Merchant $R$, Chartrand D, Dain $S$, et al. Guidelines to the practice of anesthesia-revised edition 2015. Can J Anesth 2015; 62: 54-79.

41. Neal JM, Mulroy MF, Weinberg GL, American Society of Regional Anesthesia and Pain Medicine. American Society of Regional Anesthesia and Pain Medicine checklist for managing local anesthetic systemic toxicity: 2012 version. Reg Anesth Pain Med 2012; 37: 16-8.

42. Mochizuki T, Sato S. Hypocapnia prolongs bradycardia induced by bupivacaine or levobupivacaine in isolated rat hearts. Can $\mathrm{J}$ Anesth 2008; 55: 836-46.

43. Weinberg GL. Treatment of local anesthetic systemic toxicity (LAST). Reg Anesth Pain Med 2010; 35: 188-93.

44. Wallmuller $C$, Sterz $F$, Testori $C$, et al. Emergency cardiopulmonary bypass in cardiac arrest: seventeen years of experience. Resuscitation 2013; 84: 326-30.

45. Ozcan MS, Weinberg G. Intravenous lipid emulsion for the treatment of drug toxicity. J Intensive Care Med 2014; 29: 59-70.

46. Mirtallo JM, Dasta JF, Kleinschmidt KC, Varon J. State of the art review: Intravenous fat emulsions: current applications, safety profile, and clinical implications. Ann Pharmacother 2010; 44: 688-700. 